\title{
CRITERIAL APPROACH TO ESTIMATION OF INVESTMENT EFFICIENCY IN INFRASTRUCTURE OF JSC "RUSSIAN RAILWAYS"
}

\author{
I. Yu. Solskaia \\ Irkutsk State Transport University \\ Irkutsk, the Russian Federation \\ Irina_Solskaya_@mail.ru
}

\author{
N. B. Grosheva \\ Irkutsk State University \\ Irkutsk, the Russian Federation \\ grosheva@buk.irk.ru
}

\begin{abstract}
The concept of economy's infrastructure component priority development assumes a significant increase in investment in new construction projects and an increase in the capacity of the railway infrastructure in Russia. Macroeconomic efficiency of the investment program is the most important instrument for achieving the strategic goals of JSC Russian Railways (JSC Russian Railways) in the conditions of the industry reform. The company consistently implements the tasks of optimizing the investment process by switching to the design principles of formation and management to implement the investment program of JSC Russian Railways. Evaluation of project investment efficiency should take into account, apart from the sources of their formation, the possibility of reducing operating costs. The article discusses the limitations of traditional approaches to investment evaluation criteria, conditioned by the nature of the projects implemented, and suggests modification of the approach using the criterion indicator based on the estimation of capital costs and operating expenses.
\end{abstract}

Keywords-investment program; transport strategy; evaluation of project investment efficiency; infrastructure of railway transport; operating costs

\section{INTRODUCTION}

The advanced development of the transport infrastructure is an indispensable condition for the introduction of new technologies and improved rolling stock of rail transport, first of all, due to the development of high-speed traffic, as a prerequisite for increasing the competitiveness of the transport system of the Russian Federation.

The Transport Strategy of the Russian Federation [1] is aimed at the formation of a unified transport space of Russia on the basis of a balanced advancement of the effective transport infrastructure.

The strategy provides accessibility and quality of transport services for residents in accordance with social standards, ensuring accessibility and quality of transport and logistics services in the field of freight transport, integration into the global transport space, implementation of the transit potential of the country, improving the transport system safety.

Since the efficiency of the transport system is estimated mainly through the financial result, the assessment of the economic security of the company as a result of the implementation of the investment program mainly uses the traditional method of assessing the financial aspects of the project.

However, the long-term nature of transport infrastructure development projects implies the development and modification of traditional methodological approaches based on target setting of railway's production analysis and financial activities as a key element of the transport system railway segment and the regulation of traffic volume and key quality indicators.

\section{RESEARCH}

Evolution of JSC "Russian Railways" assumes, within the framework of the base scenario implementation, the completion of the level of investments to 5506 billion rubles in 2017-2025. At the same time, the estimated share of depreciation should be $44.1 \%$ and amount to 2429 billion rubles; net profit - $14.6 \%$ and amount to 803 billion rubles.

Thus, the level of the key indicator of economic security which characterizes financial sustainability, namely the longterm debt ratio, which shows how much of the constant capital is financed, or the extent to which the enterprise depends on long-term borrowed funds in financing its assets, will increase. This coefficient characterizes the demand in such economic transactions, which ensure the attraction of long-term borrowed capital, should amount to $49.8 \%$. and its value is projected to grow by $30.2 \%$ relative to the 2016 state [2]

Taking into account the main concepts of the Transport Strategy of the Russian Federation [1], the investment program of JSC "Russian Railways" is formed on the basis of the following priorities:

- public importance: the investment program included priority objects that are effective not only for Russian Railways, but also a multiplier effect for the transport system and the economy of the country as a whole; 
- technological requirement: the investment program takes into account the need of Russian Railways to update the retiring assets that ensure the technological stability of the company and the safety of the transport process;

- economic efficiency: projects with higher economic efficiency indicators are included in the investment program.

The structure of Russian Railways' investment sources for the period up to 2025 is planned taking into account the solution of these strategic tasks as follows (figure 1).

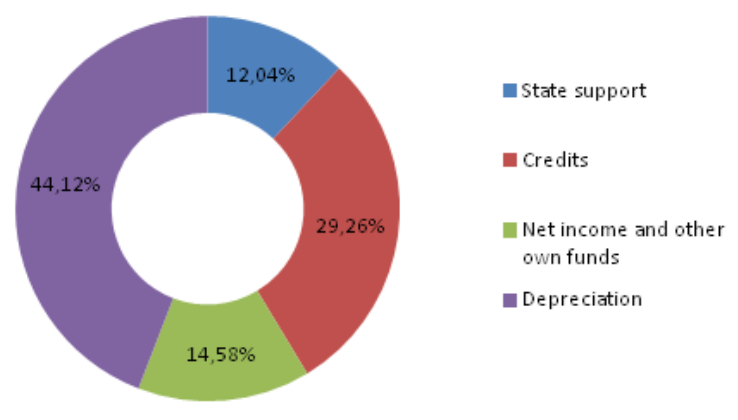

Fig. 1. Sources of investments (base scenario) 2017-2025(Source: Head of Corporate Finance Department Liulchev K.M. Main approaches and tools to ensure financial stability of the Company in 2018 and in the long term Chelyabinsk on October 4-6, 2017)

During the formation of the investment program of JSC «Russian Railways» the classical principle of coherence of financing sources and the investment program structure is used.

Thus, the Company seeks to consolidate financing of the investment budget directed to:

- the renewal of fixed assets at the level of depreciation;

- the commercially effective projects at the level of borrowed funds;

- the commercially inefficient projects at the level of state support.

A special place in the infrastructure development projects of JSC "Russian Railways" takes the development of the eastern range of railways in Russia. The need to implement these projects is conditioned by the need to reduce the infrastructure constraints that impede the full-scale development of the region's natural resources, increase the level of population mobility, and effectively integrate economic entities.

Prospects for the development of the Russian economy are associated with the development of large deposits of Eastern Siberia, the development of which will require the formation of a new and modernization of the existing transport infrastructure. Investment project "Modernization of the railway infrastructure of the Baikal-Amur and Trans-Siberian railways with the development of throughput and carrying capacity" by Order No. 2116-r of the Government of the Russian Federation of October 24, 2014, is one of the latest infrastructure initiatives aimed at developing Russia's transport and economic ties with the countries of the AsiaPacific Region and improving the conditions for industrial development in Siberia and the Russian Far East [2].

The project of reconstruction and modernization of the Baikal-Amur and Trans-Siberian railway lines or the "Eastern Range" is aimed at achieving the goals defined in the Strategy for the Development of Railway Transport in the Russian Federation until 2030, approved by Decree of the Government of the Russian Federation No. 877-r of June 17, 2008, is a part of the target indicators: the length of public railway lines with capacity limitations, the development of capacity of the existing infrastructure, traffic volume, freight turnover (table $1)$.

TABLE I. KEY CHARACTERISTICS OF THE EASTERN RANGE OF JSC "RUSSIAN RAILWAYS"” DEVELOPMENT

\begin{tabular}{|c|c|c|}
\hline \multirow[b]{2}{*}{$\begin{array}{l}\text { Main } \\
\text { charac } \\
\text { teristic } \\
\text { s: }\end{array}$} & \multicolumn{2}{|c|}{ The Baikal-Amur Mainline } \\
\hline & $\begin{array}{l}\text { The total length is } 4287 \mathrm{~km} \text {; } \\
\text { The number of regions covered is } \\
\mathbf{5} \text {. }\end{array}$ & $\begin{array}{c}\text { The Trans-Siberian } \\
\text { Railway }\end{array}$ \\
\hline $\begin{array}{l}\text { East } \\
\text { polygon }\end{array}$ & $\begin{array}{l}\text { Taishet-Sovgavan } \\
\text { The length is } 4287 \mathrm{~km} \text {; } \\
\text { Capacity at various sites: from } \\
16 \text { to } 123 \text { (min / max) p / p per } \\
\text { day; } \\
\text { The carrying capacity of } 20 \\
\text { million tons per year. }\end{array}$ & $\begin{array}{l}\text { The total length is } 9288 \\
\mathrm{~km} \text {; } \\
\text { The number of regions } \\
\text { covered is } 12 \text {. }\end{array}$ \\
\hline
\end{tabular}

Expert estimates of the total amount of necessary funding vary, but the approximate amount of investment needed to develop the BAM throughout its length for the period to 2020 is about 400 billion rubles.

According to the passport of the investment project "Modernization of the railway infrastructure of the BaikalAmur and Trans-Siberian railway lines with the development of throughput and carrying capacity," total investments in the project are estimated at 562.4 billion rubles, of which 302.2 billion rubles. is necessary to provide to OAO RZD. 150 billion rubles is the money of the National Welfare Fund (NWF), 110.2 billion rubles is subsidies from the budget [4]. Investments should be made gradually (table 2).

The evaluation of the investment special place in the development of the eastern range of JSC «Russian Railways» is due to several circumstances:

1. There is a significant predominance of the implementation phase share in the project cost compared with projects implemented in other regions due to the relief and climatic difficulties.

2. There are the prospects to attract private financing in the framework of public-private partnership tools.

3. The need for the development of social infrastructure in infrastructure projects implementation is grounded by the specifics of the eastern landfill territories [3]. 
TABLE II. THE SOURCES OF FINANCING THE IMPLEMENTATION OF THE PROJECT "MODERNIZATION OF THE RAILWAY INFRASTRUCTURE OF THE BAIKAL-AMUR AND TRANS-SIBERIAN RAILWAYS WITH THE DEVELOPMENT OF THROUGHPUT AND CARRYING CAPACITY" [4]

\begin{tabular}{|l|c|c|c|c|c|c|}
\hline \multirow{2}{*}{$\begin{array}{c}\text { Financing } \\
\text { Source }\end{array}$} & \multicolumn{5}{|c|}{ Period } \\
\cline { 2 - 7 } & $\mathbf{2 0 1 3}$ & $\mathbf{2 0 1 4}$ & $\mathbf{2 0 1 5}$ & $\mathbf{2 0 1 6}$ & $\mathbf{2 0 1 7}$ & Total \\
\hline Total, mln. r. & 35901 & 90631 & 135025 & 178449 & 122427 & 562436 \\
\hline $\begin{array}{l}\text { Including: } \\
\text { federal } \\
\text { budget } \\
\text { means of the } \\
\begin{array}{l}\text { National } \\
\text { Welfare } \\
\text { Fund, mln. }\end{array}\end{array}$ & 4620 & - & 21484 & 40167 & 43945 & 110217 \\
\cline { 2 - 7 } & - & 50000 & 50000 & 50000 & - & 150000 \\
\hline $\begin{array}{l}\text { JSC Russian } \\
\text { Railways, } \\
\text { mln. }\end{array}$ & 31281 & 40631 & 63540 & 88282 & 78482 & 302219 \\
\hline
\end{tabular}

When formulating the investment program of JSC «Russian Railways», the classical principle of coherence of financing sources and the investment program structure is used.

Thus, the Company seeks to consolidate financing of the investment budget directed to:

- the renewal of fixed assets at the level of depreciation;

- the commercially effective projects at the level of borrowed funds;

- the commercially inefficient projects at the level of state support.

In JSC «Russian Railways» the whole package of investment projects was classified according to the criterion of recoupment and commercial efficiency in three categories. The first category includes projects whose payback is reached on the horizon of 10-15 years and which OAO RZD is ready to finance through its own cash flow, as well as borrowed funds within the permissible level of debt load. The second category includes projects whose payback period is 15-30 years. These projects cannot be financed by JSC Russian Railways due to the borrowed sources.

Thus, we can assume that in accordance with the established in business "inofficial hierarchy" of funding sources [5. 264] which is represented in the sequence: undistributed profits, and if the retained earnings are insufficient, borrowed capital is used; if the borrowed capital is not enough, the share capital will be used.

Taking the clause about the "informal hierarchy" as a working hypothesis, it can be assumed that among the four projected for 2017-2015 sources of financing eastern landfill infrastructure development projects, two of the fixed investment areas should be financed from their own sources, first of all, the renewal of fixed assets at the level of depreciation.

Commercially effective projects at the level of borrowed funds are projected to be financed by loans and borrowings. At the same time, such commercially inefficient projects as the eastern landfill development should be financed including a significant amount of state support.

In accordance with the estimated value of the debt ratio, the share of assets financed from the debt funds should be $49.8 \%$.

With this version of the investment program, it is necessary to analyze the consequences of this method of the investment program formation in accordance with the goals of structural reforms implemented by JSC Russian Railways and not fully implemented at the first two stages of the structural reform, namely:

- completion of the creation of joint-stock companies on the basis of property, which is allocated to independent structural divisions of the OJSC "Russian Railways" in accordance with the established procedure;

- increasing the investment attractiveness of the railway transport.

Based on the analysis of the forecasted dynamics of net present value (NPV) and on the present value of growth prospects (PVGO), it is possible to evaluate the shares of JSC «Russian Railways» in case of their perspective emission in the forecast period (table 3 ).

Having estimated the ratio of NPV and PVGO due to the assumptions about change rates of transportation costs and revenues, it is possible to make conclusions about investors' expectations on the future performance and investments, namely:

- negative net present value assumes the need to invest in the investment projects of JSC «Russian Railways», even in conditions of profit reinvestment at the rate below market capitalization;

- positive present value of growth prospects characterizes the relationship between growth rates and market capitalization rate; being obtained, the growth rate is less than the market capitalization.

TABLE III. FORECAST AND ESTIMATION OF FINANCIAL RESULTS AND THE EFFECT OF THE INVESTMENT PROGRAM IMPLEMENTATION OF RUSSIAN RAILWAYS (2017-2025), MLN. R

\begin{tabular}{|c|c|c|c|c|c|c|}
\hline \multirow[t]{2}{*}{ Year } & \multirow{2}{*}{$\begin{array}{c}\text { Transporta } \\
\text { tion } \\
\text { expenses }\end{array}$} & \multirow{2}{*}{$\begin{array}{l}\text { Debt on } \\
\text { loans and } \\
\text { credits }\end{array}$} & \multicolumn{2}{|c|}{$\begin{array}{l}\text { Income from } \\
\text { transportations }\end{array}$} & \multirow[t]{2}{*}{$N P V$} & \multirow{2}{*}{$\begin{array}{l}\text { Present } \\
\text { value of } \\
\text { growth } \\
\text { prospects }\end{array}$} \\
\hline & & & $\begin{array}{l}\text { base } \\
\text { scenario }\end{array}$ & $\begin{array}{l}\text { stress } \\
\text { scenario }\end{array}$ & & \\
\hline 2017 & 1477,40 & 1164,70 & 1477,40 & 1462,63 & $-109,44$ & $-1543,32$ \\
\hline 2018 & 1595,50 & 1270,90 & 1595,50 & 1579,55 & $-104,38$ & $-1713,65$ \\
\hline 2019 & 1579,56 & 1285,39 & 1611,44 & 1595,33 & $-66,47$ & $-1188,80$ \\
\hline 2020 & 1595,34 & 1300,04 & 1627,54 & 1611,27 & $-59,92$ & $-1177,01$ \\
\hline 2021 & 1611,28 & 1314,85 & 1643,81 & 1627,37 & $-60,52$ & $-1176,00$ \\
\hline 2022 & 1627,38 & 1329,84 & 1660,23 & 1643,63 & $-61,12$ & $-1186,10$ \\
\hline 2023 & 1643,64 & 1345,00 & 1676,82 & 1660,05 & $-61,74$ & $-1212,64$ \\
\hline 2024 & 1660,07 & 1360,33 & 1693,58 & 1676,64 & $-62,35$ & $-1224,76$ \\
\hline 2025 & 1676,65 & 1375,83 & 1710,50 & 1693,39 & $-62,98$ & $-1237,00$ \\
\hline
\end{tabular}


The main reason for the identified trends in the economic development of Russian Railways is the costly nature of most of the company's assets: at the end of 2016, the share of fixed assets in property is $78.7 \%$.

The situation is aggravated by the fact that at the same time, the utilization (asset turnover) of assets (income / assets) decreased by 2 percent due to assets growth on account of revaluation of fixed assets (520.1 billion rubles) and the increase in unfinished construction on account of state projects which implementation and obtained results are planned in subsequent periods [6]. The identified trends kept in 2017.

Deliberately low efficiency of investments in infrastructure, calculated with traditional methods, makes it possible to assess exclusively the commercial attractiveness of new transport construction projects. However, the implementation of investment projects in the infrastructure requires the study of opportunities to reduce operational (operational) costs (OPEX).

The main characteristics of capital expenditures (CAPEX) is the duration of their use. This also means the duration of the investment development period and a significant payback by reducing operating costs of JSC "Russian Railways".

The mechanism (CAPEX) assumes that the capitalized amount of expenditures on targeted loans is reduced by the amount of investment income received as a result of a temporary investment of the part of the funds that will be spent on the asset later.

In accounting, CAPEX leads to the capitalization of costs in the balance sheet, which in turn increases the value of assets and the net profit of the reporting period (as incurred in the current period, costs are capitalized and then amortized over several years). However, capitalization of costs has drawbacks. First, the company will pay a large amount of income tax. Second, the company is required to test its assets for impairment on a regular basis.

CAPEX is carried out by companies to support or increase the scale of activities. The amount of capital expenditure largely depends on the industry in which the company operates. An example of one of the most capital-intensive industries is transport. Planned investments of the CAPEX of the track facilities The Directorate of Infrastructure of JSC «Russian Railways» should make RUR109.09 billion for the period from 2017 to 2025 ; i.e. they should increase by $34 \%$.

It is necessary to analyze OPEX - the main operating costs of track facilities with the example of the most important part of the infrastructure complex - track economy. These expenses are planned according to the articles of the Nomenclature of Income and Expenses by Types of Activities of JSC «Russian Railways»:

- the current content of the track and permanent devices,

- $\quad$ single change of materials of the track upper structure,

- maintenance of built structures, as well as protective plantations,

- guarding the track, crossings and built structures,
- snow, water and sand expenses,

- $\quad$ other works of the track economy.

Having in mind the dual nature of investment in infrastructure, one can assume that the benchmark efficiency rating should take into account the balance between CAPEX and OPEX, i.e. the possibility of reducing the latter due to a greater capitalization of JSC «Russian Railways» infrastructure assets.

\section{RESULTS}

The most acceptable model to assess the effectiveness of investments is to estimate the effectiveness with a generalizing group, applying absolute, comparative and rating indicators. The criterion exponent in this model is calculated by the reduction of the result to unity, and more specifically, using the expenditure of resources. The generalization of the expenditure indicator shows what the cost of the enterprise is per 1 ruble of output.

To analyze the efficiency of work production generalizing and particular indicators of the cost intensity are calculated. The summarizing indicator is calculated as the ratio of the performed work cost which increases capitalization. A particular indicator of the cost intensity is calculated as depreciation - the ratio of the cost of work performed, to the depreciation of the infrastructure object. It shows how much depreciation is accounted for by one ruble of work performed. Growth of the fixed capital of JSC «Russian Railways» due to new construction and (or) modernization of the infrastructure at the eastern range leads to increase in depreciation.

The proposed criterial approach to assessing the effectiveness of investment in infrastructure was tested when a third-party organization was chosen. It carried out the restoration of the track upper structure, namely the replacement of defective rails.

The obtained results can serve as a convincing evidence of a selective choice of third-party organizations - service providers carried out on a contractual basis. They can also be used for other types of work aimed at implementing infrastructure projects.

\section{CONCLUSION}

Summarizing the results of the study, the following conclusions can be made:

- the specifics of the present stage of rail transport development, conditioned by structural changes, is connected with the formation of a client relations system carried out on a contractual basis according to the results, including competitive procedures;

- a reasonable choice of the service provider should be based on the criterion evaluation of the decisions due to their economic feasibility;

- the criteria of choosing the organization to solve the tasks of transport infrastructure development must consider asset capitalization increase and further operational cost reduction. 


\section{References}

[1] Order of the Government of the Russian Federation "On Amendments to the Transport Strategy of the Russian Federation" dated 11.06.2014 No. 1032-p (electronic document), Consultant Plus, http://www.consultant.ru/law/hotdocs/34693.html/ (circulation date February 27, 2018).

[2] V. V. Burovtsev, I. Yu. Solskaya, "Modernization of the eastern range of railways of Russia in the scenario conditions of institutional transformations", Issues of the New Economy, vol. 2, pp. 61-74, 2017.

[3] I. Yu. Solskaya, O. A. Ryabushchenko, A.V. Ivanovskiy, "Project approach to managing new transport construction: monograph", Irkutsk: IrGUPS, 2016.

[4] Yu. Krupnov, "Transsib "version 2.0" as an instrument for restoring transit potential and the basis for Russia's survival in 2020-2030", Transport of the Russian Federation, vol. 2, pp. 4-5, 2010.

[5] P. Etril, Financial management for non-specialists, 3rd ed, St. Petersburg: Peter, 2006.

[6] Annual report of Russian Railways for 2016: assets, capital, liabilities of Russian Railways (electronic document), Official site of Russian Railways. https://ar2016.rzd.ru/en/financial-results/key-results (circulation date February 27, 2018). 